This PDF is a selection from an out-of-print volume from the National Bureau of Economic Research

Volume Title: International Volatility and Economic Growth: The First Ten Years of The International Seminar on Macroeconomics

Volume Author/Editor: Georges de MÃ@nil and Robert J. Gordon, editors

Volume Publisher: Elsevier Science Publishers B.V., 1991

Volume ISBN: 0-444-89284-2

Volume URL: http://www.nber.org/books/de_m91-2

Conference Date: various

Publication Date: January 1991

Chapter Title: Housing Markets, Unemployment and Labour Market Flexibility in the U.K.

Chapter Author: Gordon Hughes, Barry McCormick

Chapter URL: http://www.nber.org/chapters/c11677

Chapter pages in book: (p. 83 - 114) 


\title{
HOUSING MARKETS, UNEMPLOYMENT AND LABOUR MARKET FLEXIBILITY IN THE UK*
}

\author{
Gordon HUGHES \\ University of Edinburgh, Edinburgh EH8 $9 J \mathrm{Y}, U K$ \\ Barry McCORMICK \\ University of Southampton, Southampton SO9 5NH, UK and \\ Cornell University, Ithaca, NY 14850, USA
}

\section{Introduction}

Since the recent dramatic rise of unemployment levels in Europe, and the comparatively high level of employment growth achieved in Japan and in the U.S., increasing emphasis has been placed upon the 'inflexibility' of European labour markets. The observation that a market is 'inflexible' may not, of course, be a useful indicator of its efficiency, but we can be confident that inflexibilities arising as an unanticipated consequence of government policies reflect efficiency losses and not optimizing behaviour. Our purpose in this paper is to consider one such welfare-reducing barrier to efficient labour mobility.

British policy-makers have intervened extensively in the housing market since the turn of the century in ways which appear likely to influence the functioning of the labour market. Unfortunately, these influences were almost entirely unintended side-effects of housing policies, rather than the secondbest consequences of a unified view of the likely outcomes for both markets. While the cost of this myopic approach can be mis-stated and exaggerated, it remains an outstanding example of the need to consider the ramifications of policy beyond the market which is directly affected. The purpose of this essay will be to draw together our understanding of these spillovers paying particular attention to any implications for macro-economic modeling of labour markets. In keeping with this objective, and in order to address

*We are grateful to the discussants and participants at the seminar and to Vic Possen for helpful comments on earlier drafts of this paper. We are also grateful to the U.K. Office of Population Censuses and Surveys and the ESRC Data Archive who provided the survey data used in our work. Barry McCormick would like to acknowledge financial support from the ESRC under project F00230102 on Labour Market Flows and Unemployment. We are solely responsible for the interpretation of the data and for other views expressed in this paper. 
questions concerning labour market flexibility, we shall distinguish the following indicators by which economists might view flexibility to have been influenced by a micro policy or market structure.

(1) The nature of the short-run wage/employment response to an aggregate demand shock, and the period of time required to adjust to the long-run equilibrium.

(2) The short and long run response to a change either in the composition of demand or a 'supply shock'.

(3) The value of the equilibrium (NAIRU) rate of unemployment and its regional distribution.

The rest of the paper is organized as follows. In section 2, we discuss how housing market policies have affected inter-regional migration and, since our ultimate concern is largely with unemployment, the relationship between unemployment and migration. This theme is extended in section 3 by examining the links between job mobility and housing movement in order to establish the importance of the apparent constraints imposed by the U.K. housing system on labour mobility. In section 4 we discuss how this evidence may be of value in understanding the patterns of inflexibility and unemployment that is observed in the U.K. Section 5 concludes the paper with a discussion of policies which might ameliorate the worst side-effects of U.K. housing policies.

\section{Housing and unemployment: Implications for geographic mobility}

The implications of housing market policies for geographic labour mobility can be largely explained in terms of the consequences of these policies for the pattern of house tenure in the U.K. Three major policies have influenced the evolution of house tenure patterns in the U.K.: that of constructing and retaining in public ownership a large amount of primarily blue-collar rental accommodation (council housing); the application of rent controls to large proportions of the private sector; and tax relief on loans to house-purchasers. These policies have all served to squeeze the private rental sector, so that, whereas seventy years ago about $90 \%$ of households lived in private rental accommodation, less than $12 \%$ presently do so. About $28 \%$ of British households live in publicly owned accommodation and over $60 \%$ are owneroccupiers.

The dramatic contraction of the size of the private rental sector and the remaining excess demand for its services have almost totally undermined that sector's familiar function of supplying short-term housing for migrants into an area. This has amplified the weaknesses in the operation of the council housing system which itself discourages migration by its tenants. Having little access to private rental housing, council tenants wishing to migrate who 
are unable or unwilling to purchase a dwelling must obtain council housing in their destination region. To locate suitable accommodation council tenants are expected to rely upon council house exchanges/transfers; if there are unequal number of households seeking to enter and leave an area some workers will be 'rationed' out of an exchange. Such an imbalance is inevitable given the asymmetry of the U.K. labour market: the largest stocks of council housing are located in regions of high unemployment, from where workers are likely to want to migrate.

There are, therefore, clear arguments as to why the linkage between tenure and migration is likely to be quite different in the U.K. from that in the U.S. The large majority of rental tenants are likely to find the costs of migration both greater and more uncertain than is normally associated with the rental market. However, the tenure-migration linkage is complicated by the simultaneous influence of migration plans on tenure choice. We believe this to be unimportant in the U.K. for all but relatively few households; the following simple model explains the basis for this view.

Assume that individuals reside in one of three tenures: owner-occupation (OO), unfurnished rental (UR) - which is rent-controlled and includes council housing $(\mathrm{CH})$ - and furnished rental (FR), which is not fully controlled. Initially, let us assume that households do not intend to migrate. There is rationing of both OO housing - in the sense that households may not borrow freely at going interest rates - and UR housing. Empirically it is also reasonable to assume that in the absence of rationing, all households will choose to occupy either OO or UR housing, with the choice between these tenures depending upon rents, interest rates and household characteristics. FR accommodation would then only be occupied by households rationed out of one or both of the primary tenures.

Now, suppose that some households take account of the gains from migration net of the costs of moving house when choosing tenure. Moving into or out of a dwelling in the rental sector is relatively inexpensive, but movement into or out of $\mathrm{OO}$ housing is relatively expensive. Thus, any household that in the absence of migration opportunities would enter $O O$ might in the presence of such opportunities decide not to do so prior to migrating; conversely a household that in the absence of migration opportunities would move out of $\mathrm{OO}$ would not be (much) affected by migration possibilities. Tenants in FR considering moving into $O O$ would have to balance the financial savings from changing tenure against the additional expected costs of migrating from OO. Likewise tenants in UR who because of changed personal circumstances now prefer $O O$ must balance the utility so gained against the higher cost of migration from OO. Still, the importance of this influence is substantially attenuated by (i) the considerable financial incentives to move from FR to $O O$ and (ii) the small number of moves from UR to OO. 
To capture the effect of (i) in a simple manner we may suppose that the intention to migrate will only discourage a household's move from FR to $\mathrm{OO}$ if it intends to migrate within $\mathrm{h}$ months. The value of $\mathrm{h}$ will increase with (a) the costs of buying and selling OO houses, and (b) the expected relative price of $\mathrm{OO}$ housing services relative to FR housing services. Our estimates yielded values of $h$ in the range 12-14 months for most households in the early 1970s and the relative movements of rents, interest rates and house prices during the subsequent decade tended to reduce rather than increase the value of $h$. As a comparison Shelton (1968) suggested that $h$ was of the order of $3 \frac{1}{2}$ years in his analysis of the comparative costs of owneroccupation and rental in the United States. Thus, while we are not entirely justified in treating tenure as an exogenous variable in our estimates, it would appear that the existence of rationing, together with the financial advantages of owner-occupation and unfurnished rental vis-a-vis furnished rental, will greatly limit the influence of migration plans on the choice of household tenure prior to migration.

This analysis suggests that, as a result of ignoring this selection bias, OO should be found to be associated with less migration, and both FR and UR with more migration, than would be the case if the bias was removed. Thus, comparisons made below between council tenancy and owner-occupation may, if anything, overstate the migration rates of council and private tenants relative to those of owner-occupiers.

\subsection{Evidence}

The definitions of mobility used in the evidence discussed here are largely determined by the data sets which collect sufficient information about current and past circumstances to perform the necessary estimations. For Britain we rely upon the General Household Survey (GHS) for 1973 and 1974 and the Labour Force Survey (LFS) for 1983 which are made available to researchers with individuals identifiable only in terms of the following regions: North, North-West, Yorks/Humber, East Midlands, West Midlands, East Anglia, Greater London, South-East, South-West, Wales, Scotland Northern Ireland is not covered by the GHS and has been excluded from our analysis of the LFS data. We shall describe a migrating household as one in which the current address is in a different region to that one year previously. Unfortunately, the LFS does not distinguish between Greater London and the rest of the South East in recording the previous residence of the household, so that in some of the tables our definition of migration excludes moves between these two (sub)regions. In such cases comparisons with the GHS data have been performed on a consistent basis. A moving household is one moving house in the past year to any destination. For comparative purposes we have used data from the family data tape of the 
Michigan Panel Survey of Income Dynamics (PSID) for 1980. The nature of this data means that our figures will refer to migration/movement rates for heads of households who are members of the labour force. For Britain gross migration/movement rates for workers who are not heads of households are very similar to those for heads of households, so little seems to be lost as a result of this restriction. In order to limit the impact of migration/movement associated with the beginning and end of working lives we have restricted our attention to those aged between 21 and 64 years.

It is often conjectured that British workers are less likely than workers in other countries to migrate between regions, so it is interesting to begin our empirical analysis with some basic statistics concerning this point. We are not aware of any detailed comparative study of this proposition based upon cross-section data and, in any case, comparisons between geographically different countries are not easy to make. In table 1 we give migration and movement rates calculated from our three datasets for all heads of households, for 'young' (age <35) heads of households, and for heads of households split between those engaged in non-manual and manual occupations. In the case of the GHS data for the U.K. and the PSID data for the U.S. it is possible to distinguish between those who reported that they migrated/moved for job-related reasons and those migrating/moving for other reasons. The U.K. figures on migration exclude moves between London and the South East. We regard inter-state migration in the U.S. as providing the most appropriate comparison for inter-regional migration in the U.K., since the numbers of geographical units relative to population are similar with some being large in population and/or area and some quite small. It is also interesting to compare moves across a county line with all movement in the U.S., since inter-county movement is the closest approximation to moves from one local authority district to another in the U.K. for which data is not available.

The table shows that movement and migration rates are much lower in the U.K. than in the U.S. Even when we use whichever is largest of the figures for the two British datasets, gross movement and migration rates in the U.S. are between two and three times those in the U.K. For job-related migration the ratio lies in the same range but the job-related movement rate in the U.S. is over 3.5 times that in the U.K. The pattern of the movement and migration rates for young heads of households in the two countries is similar to that for all heads of households but with somewhat higher U.K. migration rates relative to U.S. rates, especially for job-related reasons. In the U.S. the rates of movement across a county line for both young and all heads of households are typically twice the corresponding migration rates. Thus, about one-half of 'non-local' moves, most of which involve a shift from one local labour market area to another, take the form of longer distance migration, but in total these represent only about one-quarter of all changes in residence. 
Table 1

Migration and movement rates for the U.K. and the U.S. (percent of heads of households in the labour force).

\begin{tabular}{|c|c|c|c|c|}
\hline & \multicolumn{4}{|c|}{ Movement/migration rates $(\%)$} \\
\hline & \multirow[b]{2}{*}{ All } & \multirow{2}{*}{$\begin{array}{l}\text { HOH aged } \\
<35 \text { yrs }\end{array}$} & \multicolumn{2}{|c|}{ HOH occupation } \\
\hline & & & Non-manual & Manual \\
\hline (A) UK - General Household & & & & \\
\hline $\begin{array}{l}\text { Movement } \\
\text { All } \\
\text { Job-related }\end{array}$ & $\begin{array}{l}7.74 \\
0.99\end{array}$ & $\begin{array}{r}17.42 \\
2.12\end{array}$ & $\begin{array}{l}9.30 \\
1.80\end{array}$ & $\begin{array}{l}6.57 \\
0.39\end{array}$ \\
\hline $\begin{array}{l}\text { Migration between regions } \\
\text { All } \\
\text { Job-related }\end{array}$ & $\begin{array}{l}1.14 \\
0.45\end{array}$ & $\begin{array}{l}2.52 \\
1.12\end{array}$ & $\begin{array}{l}1.83 \\
0.93\end{array}$ & $\begin{array}{l}0.62 \\
0.10\end{array}$ \\
\hline $\begin{array}{l}\text { (B) UK - Labour Force Surve } \\
\text { Movement } \\
\text { Migration between regions }\end{array}$ & $\begin{array}{r}11.65 \\
1.01\end{array}$ & $\begin{array}{r}19.02 \\
1.87\end{array}$ & $\begin{array}{r}12.57 \\
1.35\end{array}$ & $\begin{array}{r}10.62 \\
0.62\end{array}$ \\
\hline $\begin{array}{l}\text { (C) US - Panel Survey of Inco } \\
\text { Movement }\end{array}$ & 1980 & & & \\
\hline $\begin{array}{l}\text { All } \\
\text { Job-related }\end{array}$ & $\begin{array}{r}26.03 \\
3.52\end{array}$ & $\begin{array}{r}43: 94 \\
6.05\end{array}$ & $\begin{array}{r}26.62 \\
2.68\end{array}$ & $\begin{array}{r}25.37 \\
4.44\end{array}$ \\
\hline $\begin{array}{l}\text { Movement across a county lin } \\
\text { All } \\
\text { Job-relaled }\end{array}$ & $\begin{array}{l}6.55 \\
1.84\end{array}$ & $\begin{array}{r}11.8 v \\
3.33\end{array}$ & $\begin{array}{l}5.96 \\
1.16\end{array}$ & $\begin{array}{l}7.21 \\
2.60\end{array}$ \\
\hline $\begin{array}{l}\text { Migration across a state line } \\
\text { All } \\
\text { Job-related }\end{array}$ & $\begin{array}{l}3.09 \\
1.16\end{array}$ & $\begin{array}{l}5.56 \\
2.12\end{array}$ & $\begin{array}{l}2.67 \\
0.59\end{array}$ & $\begin{array}{l}3.56 \\
1.80\end{array}$ \\
\hline
\end{tabular}

Sources: UK - General household surveys 1973, 1974 and Labour force survey 1983.

US - Michigan panel survey of income dynamics family tape 1980.

The most striking feature of the figures in table 1 concerns the great difference between the ratios of U.S to U.K. migration rates for non-manual and manual heads of households. For non-manual workers the U.S. migration rate is only $46 \%$ higher than the U.K. rate and when we focus on jobrelated migration the U.S. rate is less than the U.K. rate. On the other hand, for manual workers the U.S. rate for all migration is over 5.7 times the U.K. rate while for job-related migration this ratio is 18 , largely because the British rate is so low. In the U.S. both all and job-related migration rates are substantially higher for manual than for non-manual workers, but in the U.K. this pattern is reversed with much higher migration rates for nonmanual than for manual workers. Note also that in the U.S. the proportional gap between the two groups increases with the distance moved and is larger 
for job-related migration/movement than for all migration/movement. These figures provide quite strong prima facie evidence for the view that council housing has an important effect in reducing migration rates in the U.K., since it is the major institutional difference between the two countries which is specific to manual workers as few British non-manual workers are council tenants.

In order to identify the influence of council tenancy on regional migration and house movement, we have used individual data from the 1973-74 GHS to examine both migration intentions and actual migration behaviour - see Hughes and McCormick (1981, 1985). We found that migration rates for owner-occupiers are, ceteris paribus, approximately 4 times higher than for council tenants, even though differences in transactions costs would lead one to expect higher migration rates for tenants than for owner-occupiers. Of the 3658 heads of household in the 1973 GHS who had been council tenants one year earlier, only $7 \mathrm{had}$ an address in a different region in the following year, and 5 of these had been living in Greater London. Whereas council tenants outside London comprised $30 \%$ of household heads in 1973 they provided only about $3 \%$ of total migrants. Owner-occupiers comprised about $55 \%$ of household heads outside London while $53 \%$ of the migrants were owneroccupiers.

One possible objection to this finding is that council tenants are a selfselected group who are less likely to move even after factors such as age, education, industry, occupation and region are allowed for. It is noteworthy therefore that when total house movement is studied, making no distinction according to whether a regional boundary is crossed, council tenants have a movement rate which is about $60 \%$ higher, ceteris paribus, than for owneroccupiers. Thus, within local areas the council exchange system seems to work well. It is perhaps even more interesting that if intended migration is studied, council tenants are no less likely than owner-occupiers to wish to migrate, merely less successful in fulfilling their intentions. The difficulties arise where house exchanges are sought between labour market areas so that (a) the cost of collecting information may be high, and (b) there may be a substantial imbalance in the numbers of intended movers in each direction.

Figures which illustrate the separate importance of tenure as an influence upon migration rates are given in table 2. The diagonal elements in the table give the predicted average migration rate for households in each tenure category. The off-diagonal elements give the predicted average migration rates on the assumption that the households which have non-housing characteristics of those in the column tenure category behave as if they were in the row tenure category. Thus, the average migration rates of council tenants in column 2 are predicted to increase from 1.0 to 3.9 per 1000 should they become owner-occupiers. It is particularly striking to compare the figures in row 2 of the table with those in rows 3 and 4 , as these highlight 
Table 2

The impact of tenure on migration rates in the U.K.a

\begin{tabular}{|c|c|c|c|c|}
\hline \multirow[b]{2}{*}{$\begin{array}{l}\text { Alternative } \\
\text { Tenure }\end{array}$} & \multicolumn{4}{|c|}{$\begin{array}{l}\text { Predicted migration rates per } 1000 \\
\text { households currently in tenure group }\end{array}$} \\
\hline & $\begin{array}{l}\text { Owners } \\
\text { (1) }\end{array}$ & $\begin{array}{l}\text { Council } \\
\text { tenants } \\
\text { (2) }\end{array}$ & $\begin{array}{l}\text { Furnished } \\
\text { tenants } \\
\text { (3) }\end{array}$ & $\begin{array}{l}\text { Unfurnished } \\
\text { private } \\
\text { tenants } \\
\text { (4) }\end{array}$ \\
\hline (1) Owners & 9.4 & 3.9 & 16.7 & 6.7 \\
\hline (2) Council tenants & 2.5 & 1.0 & 4.5 & 1.8 \\
\hline (3) Furnished tenants & 35.8 & 15.8 & 60.2 & 25.8 \\
\hline (4) Unfurnished private tenants & 17.0 & 7.2 & 29.7 & 12.2 \\
\hline
\end{tabular}

This table is read by considering a sample of households with non-housing characteristics similar to those in the column tenure category and then imagining that these houscholds move between house tenure categories.

Source: Calculated using migration equations from Hughes and McCormick (1985) and households in 1974 GHS.

the differences between the three tenancy categories in their effect on the migration rates of specific populations. In all cases furnished tenancy implies a migration rate over 10 times as large as that for council tenancy, while the rate for unfurnished tenancy is over 6 times that for council tenancy. Since unfurnished private tenants benefit from low controlled rents and have security of tenure, it cannot merely be the availability of rent subsidies which leads to the low migration rates for council tenancy. Note also that migration rates for owners are low by comparison with those for private tenants. This is further confirmation that it is the nature of council tenancy which depresses migration, since the relative migration rates of owners and private tenants correspond to the pattern of their relative movement rates and to what one would expect on a priori grounds given the relative transactions costs for each tenure.

We can use the results of these studies to examine how far the difference between U.K. and U.S. rates of (a) migration and (b) house movement can be explained by the U.K. house tenure system. To do this we will examine predicted U.K. migration rates on the assumption that the aggregate tenure pattern is similar to that in the U.S. while holding the tenure influence on migration constant. The tenure composition of U.S. households is approximately: $65 \%$ owner-occupiers, $32 \%$ private tenants and $4 \%$ tenants in public housing, whereas for our U.K. 1973-74 sample the composition was: $53.5 \%$ owner-occupiers, $31.5 \%$ council tenants, $7.5 \%$ private furnished tenants and $7.5 \%$ private unfurnished tenants. Thus, our experiment involves a hypothetical redistribution of households out of public housing (council tenancy) 
to owner-occupation and private tenancy in order to match the U.S. tenure pattern. This has been done by assuming that, randomly, $36 \%$ of council tenants become owner-occupiers, and $26 \%$ each become private unfurnished and furnished tenants - this latter split replicates the division of U.K. private tenants between furnished and unfurnished accommodation since we have no comparable data for the U.S.

The impact of this change may be seen by comparing the first two rows of table 3. Despite the apparently large dampening effect of tenure on migration this hypothetical switch from council tenancy (which has the lowest migration rates of all four tenures) to other tenures increases overall predicted migration rates by less than one-quarter. The effect is even less for young workers than for all workers since a smaller proportion of them are council tenants. The principal reason for the relatively small impact of this tenure redistribution is that the other socio-economic characteristics of the population of council tenants, who are predominantly manual workers with few educational qualifications and are older on average than the whole population, mean their migration and movement rates are low relative to those for households in other tenure categories even after controlling for the influence of tenure. This point may be understood by comparing the figures in column 2 of table 2 with the other columns.

Another major difference between the two countries lies in the proportion

Table 3

The impact of U.S. tenure/education patterns on U.K. migration/movement rates

\begin{tabular}{|c|c|c|c|c|}
\hline & \multicolumn{4}{|c|}{$\begin{array}{l}\text { Predicted migration/movement rates } \\
\text { per } 1000 \text { households for }\end{array}$} \\
\hline & \multicolumn{2}{|l|}{ All workers } & \multicolumn{2}{|c|}{ Young workers ${ }^{2}$} \\
\hline & Migration & Movement & Migration & Movement \\
\hline (1) U.K. population characteristics & 10.6 & 56.6 & 21.8 & 121.8 \\
\hline (2) Adjusting for U.S. tenure pattern ${ }^{b}$ & 12.7 & 69.2 & 25.5 & 141.9 \\
\hline $\begin{array}{l}\text { (3) Adjusting for U.S. college } \\
\text { education patternc }\end{array}$ & 12.5 & 66.5 & 26.0 & 145.0 \\
\hline $\begin{array}{l}\text { (4) Adjusting for both U.S. tenure } \\
\text { and college education patterns }\end{array}$ & 14.7 & 79.3 & 29.8 & 165.6 \\
\hline
\end{tabular}

${ }^{\text {a}}$ Households with head aged $<35$ years.

${ }^{b}$ Based on assumption that the tenure pattern is: owners $65 \%$, council tenants $3 \%$, private tenants $32 \%$ (of which $51 \%$ are unfurnished).

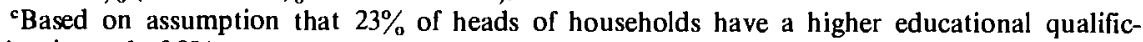
ation instead of $8 \%$.

Source: Calculating using migration/movement equations from Hughes and McCormick (1985) and households in 1974. 
of the population who have attended college or have undertaken some equivalent form of higher education or training. This is important because our analysis of migration behaviour suggests that households whose heads have acquired some kind of higher educational qualification are, ceteris paribus, more likely to migrate than are those without such a qualification. There are obvious difficulties in calculating comparable figures for the proportion of households in each country headed by someone with a higher educational qualification because of the very different character and traditions of the educational and professional training systems in the two countries. However, on a crude basis the 1981 U.K. Census figures show that $7.9 \%$ of males aged 25 or more have a degree or an equivalent professional qualification, while $23 \%$ of males in the same age group in the 1980 U.S. Census had completed 4 years of college education.

In this case the comparison with the U.S. is carried out by assuming that all of those heads of household with ' $A$ ' levels or similar qualifications (equivalent to the baccalaureat or abitur in Europe) have a college education as also do $45 \%$ of those with ' $\mathrm{O}$ ' levels (the public examination taken at age 16). The impact of these educational changes in our hypothetical population on migration/movement rates is shown in the third row of table 3. It is quite similar to that of the changes in the tenure pattern, slightly larger for young workers, who are better educated already than the average, and slightly lower for the whole population.

Putting the joint effects of tenure and college education together yields the final row of table 3. This gives predicted migration rates which are about $38 \%$ higher than for current tenure and educational patterns. It follows that, after allowing for these two major differences between the U.K. and the U.S., British inter-regional migration rates are still only one-half the level of the American inter-state migration rate for comparable households. For all house movement - which, given the difficulty of making geographic comparisons, is a less ambiguous measure of comparative mobility rates - the impact of the combined tenure and educational changes is very similar to that for migration - an increase of $40 \%$ for all workers - which might raise the predicted U.K. rate of house movement to $16.3 \%$ p.a. if we use the 1983 LFS figures as our base. This is much lower than the comparable U.S. rate of $26 \%$ p.a., so that much of the difference between the two countries in both migration and movement rates remains unexplained.

Since our ultimate concern in this paper is with labour market flexibility and unemployment, we will now outline what is known about whether unemployment in the U.K. is a stimulant to migration between geographic labour markets. Interestingly, the two basic findings here are broadly similar to those for the U.S. - see DaVanzo (1978). Our investigations of U.K. migration (Hughes and McCormick, 1981, 1985) have shown that

(a) living in a high unemployment rate region does not exercise the 
expected positive effect on actual or planned migration (and there is some evidence of a negative effect),

(b) an unemployed individual is more likely to plan to migrate (U.K.) and to actually migrate (U.S.).

An important qualification should be made to the U.K. finding concerning the migration behaviour of unemployed individuals: while there is clear evidence that being unemployed increases the intended migration rates of non-manual workers, we have been unable to detect any influence upon the intended migration rates of manual workers. Thus, if council housing has all but ended migration for the representative manual worker, there appears to be no need to qualify this for the unemployed. In a two region model of the U.K., with two types of labour, one could realistically treat one type of labour as immobile for the purposes of macro-economic analysis. This is not to rule out the possibility that depressed regions experience net total outflows of labour - probably primarily because the depressed conditions deter immigration of non-manuals rather than by encouraging emigration.

Table 4 draws upon the 1983 Labour Force Survey to illustrate the pattern of recent inter-regional labour flows and their relationship to unemployment rates. The distinction between manual and non-manual workers is crucial because of the completely different unemployment situation for the two groups. Unemployment rates are low and vary little àcross regions for non-manual workers whereas they are much higher and show a high

Table 4

Regional composition of unemployment and migration in the U.K.

\begin{tabular}{|c|c|c|c|c|c|c|c|c|}
\hline \multirow[b]{3}{*}{ Region } & \multirow{2}{*}{\multicolumn{2}{|c|}{$\begin{array}{l}\% \text { Unemployment } \\
\text { Rate }\end{array}$}} & \multicolumn{6}{|c|}{$\%$ Composition by region of $\mathrm{HOHs}$ who are } \\
\hline & & & \multicolumn{2}{|c|}{ In labour force } & \multicolumn{2}{|c|}{ In-migrants } & \multicolumn{2}{|c|}{ Out-migrants } \\
\hline & $\begin{array}{l}\text { Non- } \\
\text { manual }\end{array}$ & Manual & $\begin{array}{l}\text { Non- } \\
\text { manual }\end{array}$ & Manual & $\begin{array}{l}\text { Non- } \\
\text { manual }\end{array}$ & Manual & $\begin{array}{l}\text { Non- } \\
\text { manual }\end{array}$ & Manual \\
\hline North & 4.7 & 17.5 & 4.7 & 6.5 & 6.0 & 4.8 & 4.5 & 6.0 \\
\hline Yorks/Humber & 5.0 & 14.6 & 8.4 & 10.1 & 10.2 & 9.5 & 9.9 & 7.1 \\
\hline North West & 5.5 & 17.7 & 10.6 & 11.7 & 9.0 & 6.6 & 10.5 & 8.9 \\
\hline East Midlands & 3.2 & 9.6 & 6.7 & 8.0 & 12.4 & 11.9 & 8.1 & 11.3 \\
\hline West Midlands & 5.5 & 17.3 & 8.4 & 10.9 & 6.9 & 7.7 & 11.1 & 9.5 \\
\hline East Anglia & 4.2 & 9.2 & 3.3 & 3.9 & 6.0 & 10.1 & 6.0 & 4.8 \\
\hline London & 4.8 & 12.8 & 13.8 & 10.1 & 8.4 & 7.7 & & \\
\hline South East & 3.2 & 9.2 & 22.7 & 15.7 & 17.5 & $12.5\}$ & 27.4 & 32.7 \\
\hline South West & 3.8 & 9.6 & 8.3 & 8.0 & 16.6 & 17.3 & 10.8 & 10.7 \\
\hline Wales & 3.8 & 17.1 & 4.0 & 5.3 & 2.4 & 5.4 & 6.0 & 4.8 \\
\hline Scotland & 4.1 & 15.1 & 9.1 & 9.6 & 4.5 & 6.6 & 5.4 & 4.2 \\
\hline Total sample & & & 21633 & 25856 & 332 & 168 & 332 & 168 \\
\hline
\end{tabular}

Source: Labour Force Survey 1983. 
degree of regional variation for manual workers. Migration rates - which, as explained above, exclude moves between London and the South East in this source - are low for both groups but the non-manual rate of $1.5 \%$ is over twice the manual rate of $0.65 \%$. There is no significant relationship between net migration and unemployment rates for either group. London and the South East together experienced net out-migration of both non-manual and manual workers - especially the latter - despite relatively low unemployment rates while regions such as Yorks/Humber, Wales and Scotland experienced a net inflow of manual workers despite relatively high unemployment rates. The major systematic patterns seem to be

(a) the movement of both manual and non-manual households to the South West (Britain's sunbelt!),

(b) an eastward movement out of the North West and the West Midlands to Yorks/Humber, East Midlands and - for manual workers - East Anglia.

\section{Job mobility and house movement}

The evidence presented in the previous section indicates that the restraints on migration associated with British council housing tend to reduce the overall level of migration by a significant amount, though this does not account for the large difference between British and American aggregate migration rates. However, this does not demonstrate conclusively that barriers to housing mobility inhibit job flexibility, since it is possible that potential job changers are more successful than other council tenants in achieving council house transfers - either because they are more persistent or because they are treated more favourably by local authority housing administrators. To investigate this point and related issues concerning the link between housing and labour mobility we have estimated a number of models.

The principal work to be discussed here examines the effect of house tenure on the probability that a household will migrate/move for job-related reasons. This analysis may be carried out by estimating logit equations for the probabilities that a household actually migrated/moved (past migration/ movement) or is seeking to do so (potential migration/movement) for jobrelated reasons on two bases

(a) comparing these households with all other households,

(b) comparing these households with other households which migrated/ moved or are seeking to migrate/move for any reason.

In all cases the identification of a household as a past/potential migrant/mover for job-related reasons is based on a question which asked all actual/potential movers to specify their primary reason for moving from a list of possible responses. Apart from job-related reasons, which comprised a single response 
category, the other reasons given were (in PSID parlance) consumption reasons, i.e., to obtain better/different housing, or family reasons, i.e., to move closer to relatives.

The coefficients on housing tenure in logit equations for these two sets of probabilities are given in table 5. As well as tenure categories the equations included dummy variables for socio-economic groups, for educational qualifications, for employment in the service sector, for living in a depressed region, for not being married and for having an occupational pension. Age, age squared and length of residence in the household's current/previous home were the continuous independent variables. These independent variables were included on a priori grounds as a result of our previous work on housing movement and on job mobility. We have made no attempt to obtain the most parsimonious model in each case since the role of the nontenure variables in this context is to control for the influence of extraneous factors which may be correlated with tenure. For all of the equations reported in this paper the sample consists of heads of households who are

\section{Table 5}

Tenure coefficients in logit equations for job-related movement/migration. ${ }^{a}$

\begin{tabular}{|c|c|c|c|c|}
\hline & \multicolumn{2}{|l|}{ Migration } & \multicolumn{2}{|l|}{ Movement } \\
\hline & Potential & Actual & Potential & Actual \\
\hline \multicolumn{5}{|c|}{ (A) Job-related migration/movement for all households } \\
\hline Council tenant & $\begin{array}{c}0.00 \\
(0.00)\end{array}$ & $\begin{array}{c}-0.91 \\
(1.67)\end{array}$ & $\begin{array}{c}-0.10 \\
(0.52)\end{array}$ & $\begin{array}{r}-0.87 \\
(0.82)\end{array}$ \\
\hline Furnished tenant & $\begin{array}{c}0.37 \\
(1.04)\end{array}$ & $\begin{array}{c}1.50 \\
(5.01)\end{array}$ & $\begin{array}{c}1.04 \\
(5.91)\end{array}$ & $\begin{array}{c}1.54 \\
(3.45)\end{array}$ \\
\hline Private unfurnished tenant & $\begin{array}{c}1.05 \\
(3.09)\end{array}$ & $\begin{array}{c}0.69 \\
(1.71)\end{array}$ & $\begin{array}{c}0.31 \\
(1.26)\end{array}$ & $\begin{array}{r}1.40 \\
(2.73\end{array}$ \\
\hline \multicolumn{5}{|c|}{ (B) .Job-related migration/movement conditional upon migration/movement } \\
\hline Cüuncil tenant & $\begin{array}{c}-0.63 \\
(1.63)\end{array}$ & $\begin{array}{c}0.67 \\
(0.36)\end{array}$ & $\begin{array}{r}-0.66 \\
(3.39)\end{array}$ & $\begin{array}{r}-1.60 \\
(2.81)\end{array}$ \\
\hline Furnished tenant & $\begin{array}{r}-0.44 \\
(1.01)\end{array}$ & $\begin{array}{c}0.10 \\
(0.14)\end{array}$ & $\begin{array}{c}0.21 \\
(1.13)\end{array}$ & $\begin{array}{r}-0.26 \\
(0.72)\end{array}$ \\
\hline Private unfurnished tenant & $\begin{array}{c}0.48 \\
(1.04)\end{array}$ & $\begin{array}{c}1.82 \\
(1.73)\end{array}$ & $\begin{array}{r}-0.60 \\
(2.32)\end{array}$ & $\begin{array}{r}-0.61 \\
(1.37)\end{array}$ \\
\hline No of positive responses & 97 & 38 & 282 & 77 \\
\hline Sample size: A & 7239 & 8067 & 15120 & 8067 \\
\hline $\mathbf{B}$ & 380 & 74 & 2326 & 446 \\
\hline
\end{tabular}

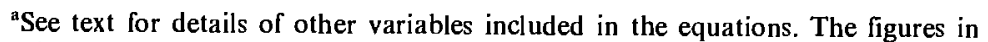
brackets are the asymptotic $t$-ratios of the coefficients. Owner-occupiers are the control tenure category.

Source: Estimated from GHS 1973/74 data. 
members of the labour force. In analysing migration/movement we are interested in labour force behaviour so that moves as a result of marriage, marital breakdown, etc. are excluded by restricting the sample to households with the same head before and after a previous move or in which the head of household was thinking of moving.

Section A of table 5 provides estimates of the coefficients on tenure in logit equations for the probability that a household migrated/moved for jobrelated reasons in the past year or is considering migrating/moving for similar reasons. In this case the sample consists of all households satisfying the criteria specified above. The default tenure category is owner-occupation so that the coefficients in the table reflect differences between the influence of the tenure concerned and owner-occupation on the probability investigated. Section B of the table gives the tenure coefficients in logit equations for the probability of past/potential migration/movement for job-related reasons conditional on migration/movement. In other words, column 1 of section B is estimated from a sample of households who were considering migration for any reason and the coefficients relate to the probability that households among this group were considering movement for job-related rather than other reasons. Similarly, column 2 of this section of the table is extracted from the equation for the probability that a household which migrated in the previous year did so for job-related rather than other reasons, while columns 3 and 4 provide the same coefficients for the probabilities of job-related movement conditional on movement.

In effect section A replicates our earlier work except that the focus is on migration/movement for job-related rather than for all reasons. The first column confirms that council tenants are as likely as owner-occupiers to seek to migrate for job-related reasons, while the second column shows that they are much less likely actually to migrate for job-related reasons. The coefficient on council tenancy is significantly less than zero on a one-tailed test, but the level of significance is low because of the very small total number of actual migrants for job-related reasons. Thus, the relative absence of job-related migrants from council tenancy, which is the source of the negative coefficient, is less significant in a statistical sense than in our previous study. In view of the results of our previous work we believe that these results reinforce the general conclusion that council tenants experience much greater difficulty than owner-occupiers in actually fulfilling their migration intentions for job-related as well as for other reasons. This is not true for tenants in general since both furnished and private unfurnished tenants are more likely to migrate for job-related reasons than are owner-occupiers. With respect to house movement, our previous investigations showed that, ceteris paribus, council tenants were more likely to move than were owneroccupiers which conforms with the predicted pattern given the differences in the costs of moving for each tenure. However, the coefficient on council 
tenancy in column 4 implies that this does not hold for job-related movement, though council tenants are similar to owner-occupiers in the probability that they are considering movement for job-related reasons. This means that the higher rate of house movement, ceteris paribus, among council tenants is associated with moves to better or more suitable accommodation rather than to more appropriate jobs. It seems, therefore, that it is not only migration which is discouraged by council housing but all forms of job-related movement. Again the contrast between council tenants and other tenants is very marked since the coefficients on furnished and private unfurnished tenancy in this equation are both significantly greater than zero. Our explanation for this pattern is that moves for consumption reasons tend to take place within a limited geographical area and, so long as council tenants remain within the district covered by a single local housing authority, council house exchanges or moves are quite easy to arrange. On the other hand, a move for job-related reasons will typically involve a move to a different local authority district and thus will encounter similar difficulties to those affecting migration over a longer distance.

Since the costs of moving for tenants are much lower than for owneroccupiers, which comprise the default tenure group in the estimated equations, one would expect that tenants would be more prone to move for non-job-related reasons than would owner-occupiers. This would imply negative coefficients on the tenancy dummy variables in the equations for job-related movement (or search) conditional on movement. However, there is no inherent reason why movement should be more or less expensive for a public tenant than for a private tenant, so that differences between the three types of tenancy are likely to reflect the way in which these tenures are restricted or controlled.

As expected there are significant negative coefficients on council tenancy and private unfurnished tenancy in the logit equations (columns 3 and 4 of table 5B) for job-related movement conditional on movement - both for potential and past movement - though in this respect there is little difference between owner-occupiers and furnished tenants. However, both types of controlled tenants are more likely to have migrated in the past for jobrelated reasons than are are owner-occupiers, which indicates the difficulty of 'casual' migration when there are rent or other controls affecting the availability of rented housing. The small number of migrants in this equation means that neither coefficient is statistically significant. The differences between the coefficients for these two tenures, which one would expect to be very similar in an unrestricted environment, are striking and they imply that council tenants are systematically less likely to migrate or move for jobrelated reasons than are private unfurnished tenants, though in the case of movement there is little difference between them in their propensity to search. 
To provide quantitative indicators of the importance of these tenure effects tables 6 and 7 follow tables 2 and 3 but with specific reference to job-related migration and movement only. Since we are primarily interested in the impact of council housing on job-related mobility table 6 focuses on the predicted values of migration and movement rates per 1000 council tenants either in their own tenure (column 2) or in the three alternative tenures - i.e., the rows in this table correspond to column 2 in table 2 . In addition to predicted mobility rates we have used the methods described in Hughes and McCormick (1985) to calculate two measures of the likelihood that someone who embarks on search to migrate/move will be successful. The first measure $\left(z_{i}\right)$ is the probability that the search is successful within a fixed period and the second measure $\left(t_{i}\right)$ is the length of time spent searching in order to achieve a fixed probability of success. Both measures are calculated using the

Table 6

Differences between council housing and other tenures in job-related migration/movement.

\begin{tabular}{|c|c|c|c|c|}
\hline & \multicolumn{4}{|c|}{$\begin{array}{l}\text { Predicted values per } 1000 \text { council tenants } \\
\text { in alternative tenure group }\end{array}$} \\
\hline & $\begin{array}{l}\text { Owners } \\
\text { (1) }\end{array}$ & $\begin{array}{l}\text { Council } \\
\text { tenants } \\
\text { (2) }\end{array}$ & $\begin{array}{l}\text { Furnished } \\
\text { tenants } \\
\text { (3) }\end{array}$ & $\begin{array}{l}\text { Unfurnished } \\
\text { private tenants } \\
\text { (4) }\end{array}$ \\
\hline \multicolumn{5}{|c|}{ (A) Mobility Rates } \\
\hline Migration & $\begin{array}{c}1.1 \\
(3.9)\end{array}$ & $\begin{array}{c}0.5 \\
(1.0)\end{array}$ & $\begin{array}{c}5.1 \\
(15.8)\end{array}$ & $\begin{array}{c}4.5 \\
(7.2)\end{array}$ \\
\hline Movement & $\begin{array}{c}4.3 \\
(23.1)\end{array}$ & $\begin{array}{c}1.8 \\
(39.9)\end{array}$ & $\begin{array}{c}18.7 \\
(155.9)\end{array}$ & $\begin{array}{c}8.6 \\
(91.3)\end{array}$ \\
\hline \multicolumn{5}{|c|}{ (B) Probabilities of Successful Search ${ }^{\mathrm{a}}$} \\
\hline Migration & $\begin{array}{l}16.3 \\
(6.6)\end{array}$ & $\begin{array}{c}6.8 \\
(1.9)\end{array}$ & $\begin{array}{c}52.3 \\
(17.3)\end{array}$ & $\begin{array}{l}23.2 \\
(7.6)\end{array}$ \\
\hline Movement & $\begin{array}{c}35.1 \\
(17.3)\end{array}$ & $\begin{array}{l}15.6 \\
(20.1)\end{array}$ & $\begin{array}{c}56.0 \\
(61.8)\end{array}$ & $\begin{array}{c}51.5 \\
(30.4)\end{array}$ \\
\hline \multicolumn{5}{|c|}{ (C) Relative Lengths of Search for Uniform Success ${ }^{b}$} \\
\hline Migration & $\begin{array}{c}3.5 \\
(11.8)\end{array}$ & $\begin{array}{c}8.5 \\
(40.8)\end{array}$ & $\begin{array}{c}1.1 \\
(4.5)\end{array}$ & $\begin{array}{c}2.5 \\
(10.3)\end{array}$ \\
\hline Movement & $\begin{array}{c}0.8 \\
(1.8)\end{array}$ & $\begin{array}{c}1.8 \\
(1.6)\end{array}$ & $\begin{array}{c}0.5 \\
(0.5)\end{array}$ & $\begin{array}{c}0.6 \\
(1.0)\end{array}$ \\
\hline
\end{tabular}

aDefined as $z_{i}$ in Hughes and McCormick (1985).

'Defined as $t_{i}$ in Hughes and McCormick (1985).

'Figures in brackets are the equivalent values for all migration/movement.

Source: Calculated from logit equations in table 4 using 1974 sample of council tenants. 
estimated equations for past migration/movement and for migration/movement search. Higher values of the probability of successful search and lower values of the relative length of search indicate that the tenure group finds it less costly or encounters less barriers to fulfilling an intention to migrate/move for job-related reasons.

The differences between council tenants and owner-occupiers in their predicted rates of job-related migration are smaller than for all migration since the hypothetical shift from council tenancy to owner-occupation doubles the rate of job-related migration for council tenants whereas this ratio is approximately 4 for all migration. The same is true for furnished tenancy when compared with council tenants, whereas the difference between unfurnished private tenants and council tenants is similar for job-related and all migration. For job-related movement the pattern is dramatically different because, as the figures for all migration/movement in brackets show, council tenants have a predicted rate of all movement which is nearly twice that of owner-occupiers whereas this relationship is reversed for job-related movement.

In most cases the probability of success in fulfilling an intention to make a job-related migration or movement is higher than for all migration/movement - for migration by council tenants it is over three times higher - but again for council tenants the probability of successful search for job-related movement is lower than for all movement. The same is true for furnished tenants though the success rates are both much higher and relatively closer together.

With respect to our interest in labour market flexibility the figures in table 6 imply that households find it substantially easier to fulfil an intention to migrate for job-related reasons than for other types of migration. The difference between council tenants and other tenure groups with respect to job-related migration rates is less than for all migration. On the other hand council tenants seem to experience substantial difficulty in organising local moves for job reasons. For example, the probability of successful search for an owner-occupier who wants to move for job-related reasons is over double the equivalent probability for a council tenant, whereas the probability of successful search to move for all reasons is slightly higher for council tenants than that for owner-occupiers. This is particularly notable in view of the higher success rate of private unfurnished tenants for job-related moves relative to all moves. Again this casts doubt on any simple interpretation of the influence of council tenancy relying upon the effect of rent subsidies.

Turning to the aggregate impact of tenure and education on job-related migration/movement the figures in table 7 show that the overall adjustments to aggregate job-related migration/movement rates due to tenure and college education differences between the U.K. and the U.S. are very similar to those for all migration/movement. They are a little smaller for young workers and 
Table 7

The impact of U.S. tenure/education patterns on U.K. job-related migration/movement. ${ }^{a}$

\begin{tabular}{|c|c|c|c|c|}
\hline & \multicolumn{4}{|c|}{$\begin{array}{l}\text { Predicted migration/movement rates } \\
\text { per } 1000 \text { households for }\end{array}$} \\
\hline & \multicolumn{2}{|c|}{ All workers } & \multicolumn{2}{|l|}{ All workers } \\
\hline & Migration & Movement & Migration & Movement \\
\hline $\begin{array}{l}\text { (1) U.K. population } \\
\text { characteristics }\end{array}$ & 4.8 & 9.6 & 10.6 & 20.8 \\
\hline $\begin{array}{l}\text { (2) Adjusting for U.S. } \\
\text { tenure pattern }\end{array}$ & 5.7 & 12.0 & 12.2 & 25.0 \\
\hline $\begin{array}{l}\text { (3) Adjusting for U.S. } \\
\text { college education pattern }\end{array}$ & 5.7 & 11.1 & 12.5 & 24.2 \\
\hline $\begin{array}{l}\text { (4) Adjusting for both U.S. } \\
\text { tenure and college } \\
\text { education patterns }\end{array}$ & 6.6 & 13.7 & 14.3 & 28.7 \\
\hline
\end{tabular}

${ }^{\text {a }}$ See notes to table 2.

Source: Calculated using migration/movement equations in table 4 and households in 1974.

a little higher for movement by all workers, but the earlier conclusions about differences between the U.K. and the U.S. apply equally to job-related movement. For job-related migration, especially by young workers, the proportional gap between the two countries is somewhat smaller than for all migration, so that after the adjustments in table 7 have been applied the hypothetical rate of job-related migration for young workers rises to about $70 \%$ of the U.S. rate.

To establish whether it is the labour market or the housing market which imposes the binding constraint on household decisions involves tricky problems of econometric modelling and, ideally, requires fuller data than we have available at present. We have attempted to investigate this issue in some incomplete work using techniques of simultaneous and recursive bivariate probit analysis. Estimation of these models is very expensive with large datasets and, unfortunately, we have not been able to obtain clear-cut results concerning the nature of the link between decisions concerning job mobility and house movement. Inferences which do appear to be valid are as follows

(a) For all households, housing search is conditioned upon job search, i.e. the probability that a household will be observed searching for a new residence is increased if the head of household is also tilinking of changing his or her job, whereas the reverse is not the case.

(b) For council tenants, past house movement and job changes appear to be 
independently determined, which is only possible if the job moves take place within the household's local labour market area.

(c) For owner-occupiers, the direction of causality for past decisions is the reverse of that for search. Thus, past house movement seems to increase the probability of a job change but not vice-versa. This means that the housing market may, in practice, be a constraint on labour market decisions made by owner-occupiers as well as for council tenants.

Overall, this evidence suggests that the housing market does constrain labour market flexibility, but the links involved are quite difficult to disentangle.

\section{Labour market flexibility and unemployment}

In the previous section we summarized evidence concerning housing and labour mobility in the U.K. In this section we examine how these relationships might affect various measures of the flexibility of the labour market and the pattern of unemployment.

\subsection{Wage fixing and adjustment to demand shocks}

Of the three parts of this section, our comments here are necessarily the most speculative. Nevertheless, the potential implications of geographic immobility for the nature of wage contracts deserve attention, and we shall discuss three ideas. First, geographic immobility may have influenced the size of the union sector. Second, game-theoretic analysis of wage determination in the context of a declining industry, as recently discussed by Lawrence and Lawrence (1985), is perhaps of heightened interest. Third, low migration rates have increased the need for differential regional wage adjustment to remove regional labour market imbalances, which may increase the difficulty of coordinating a wage policy during a depression. We now consider these points in turn.

To adopt Hirschman's terminology, trade unions provide a means for the expression of 'voice' when an issue of concern to the workforce arises. Workers may alternatively respond to the source of concern by seeking work elsewhere - the 'exit' option. When mobility is costly, workers have an increased incentive to exercise the 'voice' option and to join and be active in unions. Adopting a more traditional argument, where labour turnover is high and substitute labour can easily move into the area, the difficulties confronting a labour organiser are greater and, if a union is formed, it will have more difficulty enforcing its preferences. Thus the high unionization rate in the U.K. may partially reflect the factors contributing to geographic immobility, particularly amongst manual workers. Furthermore, the choices of unions (for example, whether to strike or not) and the adversarial character of 
management-union relations - the traditional explanation for low U.K. productivity - may also reflect the costliness of exercising the 'exit' option for many British workers. There is interesting work in this area by Freeman (1980) who considers the effects of unions on workplace turnover, but further empirical work unscrambling the related roles of geographic and workplace turnover on which firms bargain with unions would appear to offer the possibility of a richer understanding of the simultaneous determination of both workplace turnover and the size of the union sector. This leads naturally to our second point.

An interesting analysis of wage adjustment in the context of shocks to the demand for labour is provided by Lawrence and Lawrence (1985). In this model an adverse demand shock may push the firm into an optimal policy regime in which investment is terminated. Because the capital stock is no longer sensitive to the real wage, the elasticity of demand for labour declines. This reduced elasticity may prompt the union to increase the wage in the declining industry: the earnings of the firm, net of variable inputs, have become pure rents that an attentive union may sequestrate in the drawn-out decline of the firm. A policy which increases the costs of migrating between regions reduces the elasticity of supply of the labour force. This increases the incentive for the firm to engage in bargaining games to secure locational rent, and while the analogy is not exact, increases the likelihood that models of the sort studied by Lawrence and Lawrence offer an insight into how wages and employment respond to a demand shock.

Third, geographic immobility increases the importance of regional wage adjustment to clear markets, and the coordination of a deflationary wage policy in the fact of a depression is made more difficult for labour contract negotiators to reach if there exists an imbalance of excess supplies for labour across regions. Such an imbalance may not prevent an appropriate nationally agreed wage policy, but given that union representatives and firms will experience different regional circumstances, it may (a) make its need more difficult to perceive, and/or (b) increase the difficulty of achieving majority support amongst the union or firms' representatives.

\subsection{Adjustment to supply shocks and changes in the composition of demand}

Both supply shocks and changes in the pattern of demand will generally alter the equilibrium allocation of resources between regions. Barriers to geographic mobility can be expected to increase the period of disequilibrium, and perhaps also the nature of the eventual equilibrium. The higher unemployment associated with any given pattern of shocks can be expected to reduce aggregate demand because of either lower consumption or the crowding out effect of financing unemployment compensation, so that structural change exercises a larger adverse effect on aggregate demand. 
Thus, both directly and indirectly - through its effects on aggregate demand - geographic immobility is likely to increase the amplitude of employment cycles associated with these sorts of shocks.

Geographic immobility is also likely to increase the level of long-term unemployment associated with a given pattern of shocks. This may facilitate circumstances in which the NAIRU is likely to increase if the actual rate is perturbed above its previous equilibrium. That is, the 'hysteresis' or pathdependency effect may be particularly powerful in economies with geographic immobility where the ability to reabsorb redundant workers into employment is considerably reduced - see Blanchard et al. (1985), Hargreaves-Heap (1980).

Many of those becoming redundant following the recent U.K. shocks are older workers, whose incentive to migrate is already low, so that the hysteresis effect is likely to be further reinforced. If there is a tendency for seniority to be a less important criterion for deciding upon layoffs in Britain and other European countries than it is in the U.S., then the resulting consequences for the extent of long term unemployment and the force of the hysteresis effect may be important. We believe that further analysis of the effects of geographic immobility upon the tendency of workers to withdraw from job search, and of the comparative lay-off behaviours of U.S. and European firms, would be of particular value.

There is a further issue, connected with the hysteresis argument, which is relevant for the U.K. We suggested in section 2 that the evidence that labour flows out of regions of high unemployment, so that regional labour reallocations occur, is not strong. Unemployed individuals in a depressed area do not seem to have either higher actual or higher intended migration rates (and the evidence points to lower actual migration rates). The only link that has been established using individual data between unemployment levels and migration is that unemployed white collar workers are more likely to intend to migrate. (We are currently investigating the relationship between unemployment and actual migration rates). Thus, an economy with two regions which are identical except for their unemployment rates may experience a small net inflow of white collar labour into the low unemployment rate region, as a consequence of higher gross flows from the high unemployment region. Detailed evidence is not yet available concerning whether depressed regions experience lower inflows, which would certainly offer the possibility of providing a more balanced means of regional adjustment including manual workers. For this reason the consequence of high regional unemployment for the level and nature of U.K. regional inflows, must be considered a priority research topic.

We feel obliged to end these remarks with a note of caution. In view of the evidence that only white collar workers migrate from depressed areas it is presently far from apparent that, even if a net migratory adjustment is 
prompted by unemployment, it would help restore to equal prosperity the various regional labour markets. For example, consider a model in which the regional demand for labour is influenced by the entrepreneurial quality of its local labour force. Now suppose that entrepreneurship is more likely to develop amongst more able workers. If more able workers tend to be whitecollar workers, whom we know to be most likely to migrate, then the adjustment process may involve a higher outflow of potential entrepreneurs/ employers, the 'seed-corn' of future businesses providing the demand for labour, than of future employees. It is more usual in regional analyses to assume that the location of. a firm's owner is irrelevant to the location of capital, but this may be inappropriate for small businesses and thus most of the high-growth businesses.

\subsection{The level and the regional distribution of the NAIRU}

In section 2 we discussed how the housing system influences geographic mobility, and in sections 4.1. and 4.2. how the system may also affect the nature of adjustment to shocks to the level or composition of demand or supply. Now we consider other arguments concerning the effect of housing policies on the distribution of unemployment and labour shortages in the U.K. - perhaps because they cause unemployment to accumulate in areas with a high density of council housing - and on individual incentives to be unemployed. The origins of these arguments were various pieces of evidence concerning high unemployment amongst council tenants. We shall briefly consider the arguments and then interpret the direct evidence linking unemployment and tenancy.

Towns and regions with a high density of council housing are likely to experience an excess of tenants seeking to migrate out of the area over those trying to enter it. This inhibits the migration of council tenants, who will not wish to give up their location-specific housing subsidy. In contrast, the major subsidy to house purchasers is not location-specific and thus it does not frustrate migration. Over time there will be a tendency for areas with more council housing - and thus with more location-specific subsidies - to retain a larger labour stock than those with less council housing. (The argument is similar to the wage-compensating principle used by Hall (1972) where all workers in an area receive the location-specific subsidy.) While the pattern of council house construction may in this way change the spatial allocation of the labour force, it will only affect unemployment if wages are not locally flexible.

Alternatively, there are various reasons why, apart from considerations arising from geographic immobility, unemployment may systematically differ between house tenure groups. For example, the replacement-ratio for social security benefits is affected because of the different ways in which tenants and 
owners - with and without mortgages - are treated under the social security system. An argument we would emphasize concerns the role of wealth in labour supply decisions. A large proportion of the typical U.K. household's wealth is invested in housing - either in the form of an equity stake or in terms of the present value of a dependable rental subsidy. A tenant in good accommodation might well consider himself more wealthy than certain owner-occupiers with a small amount of realizable capital after allowing for house selling costs. Unfortunately, the U.K. data sets do not allow a direct investigation of how far wealth affects the length of job search but it seems possible that this factor may directly influence the relationship between house tenure and unemployment. Council tenants may also differ in unemployment behaviour in so far as they are a self-selected group with certain unobserved characteristics that influence various aspects of behaviour including unemployment.

What evidence relates house tenure and unemployment? In work based on a sample of manual workers from the 1973-74 GHS McCormick (1983) found that there was a strong correlation between tenure and the probability of being unemployed. After controlling for other observable characteristics and for regional unemployment he found that council tenants are about 3 times more likely to be unemployed than are owner-occupiers. We have reexamined this relationship using data from the 1983 LFS and again find a very strong link between unemployment and tenure with the ratio of the adjusted unemployment rates for council tenants and owner-occupiers being even larger than ten years earlier. In view of the arguments that council tenants are self selected and that unemployment may reflect inherent ability, it is interesting that the model can be applied to skilled manual workers on their own with the same outcome. Similarly, the finding cannot be explained by higher job turnover amongst tenants: job turnover is only $40 \%$ higher among tenants than among owner-occupiers.

The argument that something other than self-selection is at work suggests that areas with more council housing will have higher unemployment - this cannot be true with self-selection unless the additional assumption is invoked that some towns have more workers with the unobserved unemploymentinducing personal characteristics. Again, models of the unemployment rate in large towns in England and Wales, controlling for socio-economic composition and demand shocks, show that the proportion of controlled rental housing (council and private) has a strong positive effect on local unemployment rates though less than in individual data. (This cannot be readily explained by the argument that council housing was constructed in areas that at the time of construction were depressed: heavy building in the Midlands and North West, and relatively little in Wales are the counterexamples - see McCormick (1983) for further details.)

What may be inferred from these findings? While the tendency of council 
tenancy to inhibit migration may explain why certain regions experience labour shortages and others unemployment, we doubt for two reasons that this accounts for the higher unemployment rates of tenants found in individual data, both before and after controlling for socio-economic characteristics, unobserved heterogeneity, and regional unemployment. First, the parameters on the various tenure categories in a model of unemployment probabilities always indicate identical behaviour for tenants of private and council controlled housing, and yet only council housing reduces migration. Second, since it is never possible to reject the hypothesis that owners without mortgages have similar unemployment probabilities to the controlled rental groups, the most appropriate distinction is between owner-occupiers with mortgages and the rest. This leads us tentatively to favour the view that the wealth/incentive package for mortgages may substantially affect unemployment patterns in addition to the usual socio-economic and demand variables. Thus, if council housing can be assumed to have replaced private rental accommodation that was squeezed out by rent controls, we would argue that the individual equilibrium, and therefore the NAIRU rate of aggregate unemployment, may not have been substantially affected. At the same time, it seems entirely plausible that the pattern of relatively high unemployment rates in the depressed regions of the U.K. combined with persistent labour shortages in southern England has been aggravated by a council housing system which significantly limits the ability of manual workers to relocate from the sites of declining traditional industries in the north towards southern areas.

\section{Policy response}

There are two levels on which policy might be developed. In our view the appropriate response is not to attempt to patch up the existing system by implementing ad hoc reforms focused upon the issue of mobility but to consider the broader framework of taxation, housing finance and rent control legislation. The nature of housing finance leads to excessive investment in owner-occupied housing which involves high transaction costs and low mobility for individuals who could be expected to prefer good quality rental accommodation were there incentives to make it available. Again, a coherent policy determining local authority rents, building levels and migration arrangements, thereby providing our largest nationalized industry with a framework respecting overall national needs and not local interests would be especially advantageous. Finally, a policy of gradually removing rent controls would be especially beneficial for young mobile workers.

On a more ad hoc level there are just two points we would make regarding the management of council housing in the present framework. First, the central government should insist that local authorities fix the share 
of new lettings available to migrants at no less than a certain minimal level. Local authorities acting individually do not have the appropriate incentives to choose this variable at a socially optimal level. Second, we favour the establishment of a central unit to coordinate the location of new council housing, for at any given level of council house building local incentives in both the North and the South are likely to lead to the share of new council house construction occurring in southern England to be below the optimal level.

More generally it seems that job-related migration is low in the U.K. - at least by comparison with the U.S. though not perhaps by comparison with other countries in Northern Europe - even after we have adjusted for the major effects of tenure and education. If migration is seen as an important means of encouraging greater labour market flexibility, then the government will probably need to take action to reduce the costs of migration borne by the individual. Much job-related migration is sponsored in the sense that it arises because firms transfer workers from one part of the country to another - either as a succession of career moves or as a result of the relocation of office or production facilities. For the U.S. Bartel reports that such migration represents approximately one-third of all migration by workers, whereas the share of sponsored migration is much higher in the U.K. - in the 1973-74 and 1983 surveys about $60 \%$ of workers who had migrated in the past year and were employed a year ago were still working for the same employer. In these cases the costs of migration are usually defrayed by the firm and are tax-deductible in computing the firm's tax liability and - so long as any expenses paid are 'reasonable' - are not taxed in the hands of the migrant. On the other hand public sector employers and many firms are unwilling to meet the full relocation costs of new employees. In the U.S. such unreimbursed expenses, which are essentially an investment yielding a higher employment income flow, may be tax-deductible under the personal income tax code, whereas they are not in the U.K. A change in this direction deserves serious consideration. The reluctance of the tax authorities to create further tax expenditures - even small ones in a worthy cause - may rule out action in this direction.

The present system seems to bear hardest on manual workers. In part this is because regional wage differences are surprisingly small in money terms, and for owner-occupiers real wages are highest in areas of high unemployment where house prices are low. Thus, either an increase in regional wage differentials will be required to stimulate greater migration or a reduction in regional differentials in housing costs (both rents and house prices). Regional wage differentials seem to be much larger in the U.S. than in the U.K., which goes some way to explaining the difference in migration rates between the two countries. However, this is clearly not a complete explanation as we have seen that differences in migration rates are mirrored by similar 
differences in local movement rates, especially job-related movement, by manual workers, which cannot plausibly be ascribed to the influence of differential wage rates. The regional pattern of wages seems to have been remarkably stable despite major changes in the composition and level of unemployment, so it is clear that there is very strong institutional inertia resisting the realignment of local wage rates in response to the pressure of demand in local labour markets.

Whatever happens to regional wage differentials, any attempt to increase geographic labour mobility in the U.K. must involve a much higher rate of new housebuilding suitable for manual workers in low unemployment areas - particularly in the South East. This runs directly counter to the interests of existing residents of these areas who are benefitting from the capital gains resulting from the limited supply of housing and who also object to new building on the grounds that it will reduce the environmental benefit which they currently enjoy. Such conflicts over zoning have, of course, been a feature of Californian growth but in Britain they are given a special twist by the existence of strong planning controls combined with 'green belts' designed to stop urban sprawl in the immediate post-war period but which are now tending to strangle residential development in much of southern England. In essence U.S. zoning controls tend to be local in character whereas British ones have a much wider regional impact.

Finally, we should note that in a variety of measures the British government has attempted to encourage migration on a limited scale and there are even schemes which provide subsidies to migrating workers. The money available for such schemes is small and, in general, there seems to be little public or government support for migration as a remedy for regional unemployment differentials.

Overall, our conclusions concerning the contribution of geographic labour mobility to achieving a greater degree of flexibility in the labour market are not optimistic. The empirical work discussed above provides convincing evidence that the council housing system represents a substantial barrier to job-related local movement as well as to migration. However, even if this barrier to geographic mobility was suddenly removed so that council tenants were able to move as easily as other tenants or owner-occupiers, there would still be very large differences between U.S. and British rates of job-related migration/movement. Focusing specifically on manual workers, who are most severely affected by the operation of the council housing system, the removal of all tenure constraints on geographic mobility would increase job-related migration and movement rates by less than $75 \%$. American rates of jobrelated migration and movement for manual workers are over 10 times as large as comparable British rates, so that much more than a change in tenure arrangements would be required to close this gap. Since it is unemployment rates for manual workers which display large regional 
disparities, there seems little prospect that these will be significantly reduced as a result of geographic labour mobility in the absence of major social and institutional changes affecting both the incentive for and willingness of households to migrate/move for job-related reasons. Nonetheless, there are strong equity and efficiency arguments for removing artificial barriers to geographic mobility by manual workers, so that reforms in housing policy which contribute to this goal are clearly desirable.

\title{
References
}

Bartel, A.P., 1979, The migration decision: What role does job mobility play?, American Economic Review 69, 775-786.

Blanchard, O., et al., 1985, Employment and growth in Europe: A two-handed approach (Centre for European Policy Studies, Brussels).

DaVanzo, J., 1978, Does unemployment affect migration? - Evidence from micro data, Review of Economics and Statistics 60, 504-514.

Freeman, R.B., 1980, An exit-voice trade-off in the labour market: Unionism, job tenure, quits and separations, Quarterly Journal of Economics 94, 643-673.

Hall, R.E., 1972, Turnover in the labour force, Brookings Papers on Economic Activity 3, 709 756.

Hargreaves-Heap, S.P., 1980, Choosing the wrong 'natural' rate: Accelerating inflation or decelerating employment and growth?, Economic Journal 90, 611-620.

Hughes, G.A. and B. McCormick, 1981, Do council housing policies reduce migration between regions?, Economic Journal 91, 919-937.

Hughes, G.A. and B. McCormick, 1985, Migration intentions in the U.K.: Which households want to migrate and which succeed?, Economic Journal 95, Conference supplement, 76-95.

Lawrence, D. and R. Lawrence, 1985, Manufacturing wage dispersion: An end-game interpretation, Brookings Papers on Economic Activity 1, 47-116.

McCormick, B., 1983, Housing and unemployment in the U.K., Oxford Economic Papers 35, $283-305$.

Shelton, J.P., 1968, The cost of renting versus owning a home, Land Economics 44, 59-73.

\section{COMMENTS}

\section{'Housing Markets, Unemployment and Labour Market Flexibility in the UK' by G. Hughes and B. McCormick}

\author{
Martin N. BAILY
}

Gordon Hughes and Barry McCormick have written a first-rate paper exploring the extent to which public housing (council housing) in the United Kingdom is a barrier to migration, and hence an obstacle to labor market adjustment. They draw on their own prior work and present some new results to make a convincing case that council housing does discourage migration, but that the elimination of this mobility barrier would not help much in reducing overall unemployment. 
The authors begin with a comparison of migration and movement in the United States and the United Kingdom. Migration in the United Kingdom means a move across a regional boundary, while in the United States it is across a state boundary. Movement means any address change. The validity of their migration comparison can be questioned, because states and regions are different concepts. Moving across a state line can be as large as from New York to California or as trivial as from the New York suburbs of New York City to the New Jersey suburbs of the same city. Many migration studies of the United States try to track in more detail the nature of the move - how far, or whether it was rural to urban, and so on.

Despite this reservation, the relatively high propensity of Americans to both move and migrate comes through clearly in the data. Even if Britons had the same pattern of house tenure and education as Americans, they would move less. Most Americans are immigrants or have recent ancestors who are immigrants, so a high propensity to move is hardly surprising.

Now that Europe is facing severe long-term unemployment, the flexibility of the U.S. labor market looks attractive. But it was only a few years ago that economists were explaining why unemployment in the United States was so much higher than in Europe. The high turnover rate in the United States was often cited as a cause of high frictional unemployment and a high NAIRU. This may show that labor market institutions or patterns that work badly in one situation may work well in another. At the least it should make us hesitate to advocate social engineering.

The bulk of the Hughes-McCormick paper explores the evidence for the impact of council housing on migration. And the case is overwhelming. Council house tenants make up nearly a third of United Kingdom households and most of these households are headed by manual workers. They do move often from one council house to another in the same locality, so they are not just families that stay put. However, they very rarely leave a locality. Of the 3658 household heads in the 1973 survey, only 7 changed regions in a year, and 5 of these had lived in London.

The main question about results such as these, of course, is whether council house tenancy is a proxy for some unobserved characteristics of the individuals. Do people who want to stay put choose council housing? To some extent this must be true. If all the council housing were suddenly sold to the private sector and market rents levied on tenants, it is doubtful if the tenants would immediately migrate at the rate predicted by the authors' equations. But the impact would certainly be substantial. Moreover, in one respect their results understate the impact of council housing because many of those now living in private rental accommodation are on waiting lists for council housing, and may be just as reluctant to move as existing tenants. ${ }^{1}$

\footnotetext{
'This point was made by Martin S. Feldstein.
} 
Given that council housing reduces migration, does that make it a significant barrier to equilibrating job mobility? The authors look at reasons for migration and at the impact of unemployment on it. The results are very discouraging for anyone hoping to use housing policy to aid the labor market. Blue-collar workers do not seem to respond to differences in job opportunities as reflected in unemployment rate differences. When a region becomes depressed, the professional and white-collar workers do migrate out. But the blue-collar workers remain behind, living in council housing and being supported by unemployment compensation and other family members. The power of mobility to equilibrate the labor market in Britain is apparently very limited.

The authors raise an interesting implication of their findings about low mobility. Labor unions are stronger and more militant in the United Kingdom than in the United States. That fits, because U.S. workers are more likely to vote with their feet by moving, whereas U.K. workers do not see migration as an option and use group action in the form of a union. Strategic end-game wage bargaining is probably more common in the United Kingdom than in the United States.

The final issues remain: what should be done about housing policy in Britain and, indeed, what should be done about unemployment? It is clear that current housing policy in Britain is not optimal. It inhibits migration, for whatever reason, and is not an efficient form of income redistribution. The program to sell off council housing is apparently not working and, in any case, drastic policy changes would create upheaval. A gradual move to raise rents towards market-clearing levels seems indicated, combined with specific steps to open up council housing to in-migrants, as the authors suggest. It should be noted, however, that describing a fully efficient housing market is not easy. When a region becomes depressed, this imposes large capital losses on the owners of housing capital and infrastructure capital, whether these owners are in the private sector or public sector. A high level of migration by workers does not necessarily indicate an efficient market. Flexible regional wage rates that encourage new business investment to replace the plants that have closed may be more efficient. Unfortunately, such flexibility is apparently less in Britain than in the United States, exactly the opposite of what one would expect from the low U.K. migration rate.

The blue-collar work-force in Britain has suffered for over five years from a massive shortfall of jobs and the solution to this problem is one of doubtful feasibility. It is to combine forceful expansionary macroeconomic policies with limits on union power and a reorientation of the tax and transfer system to provide greater rewards to work. Housing policy is probably not a big player in this story. 


\title{
COMMENTS
}

\section{'Housing Markets, Unemployment and Labour Market Flexibility in the UK' by G. Hughes and B. McCormick}

\author{
Takenori INOKI
}

This paper provides convincing evidence that the council housing system in U.K. significantly limits job-related local house movement as well as labor migration. Since it is asserted in conventional economic theory that labor mobility that shifts human resources between geographic areas is of central importance to the efficient operation of labor market, the problem dealt with in this paper is highly relevant to the analysis of economic adjustment, particularly when we are concerned with the actual contents and cause of unemployment in relation to the concept of NAIRU. The points argued as well as statistical techniques employed in this paper are quite solid, and their limitations and qualifications are carefully noted. So the paper is basically self-contained and is not vulnerable to substantial criticism.

My first comment concerns the method to evaluate labor market 'flexibility' adopted by Hughes and McCormick. Job mobility and migration are usually considered to be a favorable indicator to detect the efficient operation of labor market, but the other side of the coin of mobile labor is high labor turnover which generally tends to reduce the workers' skill and productivity due to the change of their specific work place. Indeed Freeman's 'voice-exit hypothesis' focuses on such an aspect of 'exit' solution which increases recruitment and training costs of job movers and their loss of skill in the workshop. It will be interesting to know to what extent Freeman's conclusion that unions have positive effects on productivity turns out to be valid in U.K.'s industrial scene. The welfare implication of labor immobility may be a little more complex than is assumed in this paper.

Secondly, the link between employment levels and migration that was established in this paper by using individual data is that unemployed white collar workers are more likely to intend to migrate across regions. If, as the authors put it, more educated workers tend to be white-collar workers, we need some theory which explains the difference in migration behavior between the more educated and the less educated. One possible theory is given by Schwartz (1976) which was tested to be valid for the case of Japan (Inoki and Suruga (1981)), i.e., the more educated are found to be less deterred by an increase in distance. (Smaller distance elasticities of migration are observed for more educated persons.) In the U.K. case which was examined by Hughes and McCormick, it also seems that the fixity of blue 
collar workers due to the public housing system makes a contrast to the relatively (compared to the U.S. case) high migration rate of non-manual workers.

Finally, I would like to add one technical point concerning simultaneity or endogeneity of migration decision and house tenure choice. Since $I$ have no good alternative to correct the bias, my comment will be brief and only touches on the point related to my second comment. If it is the labor market, and not the housing market, which imposes the constraints upon household decisions about migration, the reason why the area of search of manual workers tends to be narrower (hence less manual workers cross regions) should be explored more thoroughly. I surmise that here we will have to partly rely upon human capital theory and upon the concept of skillspecificity.

\section{References}

Inoki, T. and T. Suruga, 1981, Migration, age and education: A cross-sectional analysis of geographic labor mobility in Japan, Journal of Regional Science 21, no. 4.

Schwartz, A., 1976, Migration, age and education, Journal of Political Economy 84, 701-719. 
